\title{
教育講演 $(1)$
}

\section{酸化ストレスとアポトーシス}

多細胞生物個体は常に外界の様々な刺激もしくはストレスに曝されている。個体 は細胞間の緊密なコミュニケーションを介して，刺激の種類や強さを認識・解読し， それらの変化にいかに対応するかを考え，もしくは反射的に行動対処している。同 様に多細胞生物体を構成する個々の細胞も様々な細胞環境の変化に常時曝されると ともに，それらに正確かつ迅速に反応することを要求されている。細胞は様々な刺 激を細胞内外のセンサーもしくはレセプターを介して認識し，瞬時にしてそれらの 変化に対する対処方法(例えば増殖，分化，死など)を決定する必要があり，そのた めに細胞の中には分子間相互作用を介した高度な細胞内情報処理システムを発達さ せていると考えられる。近年の分子生物学的技術の発展により，質(例えばリガンド の種類)の違いが産み出す生理活性(例えば増殖や死)の違いについては多くの知見 が得られ，それらを仲介するシグナル伝達機構についてもかなりの理解が得られつ つある.しかしながら，質的に同じリガンド(もしくはストレス)の量的差異が, 全 く異なる生理活性を発揮する分子メカニズムについてはほとんど明らかにされてい ない，換言すれば，細胞が刺激の量を認識するメカニズムならびに量の違いを質の 違いへと変換するメカニズムについてはほとんど研究がなされていないといえる。

我々は，(1)ストレス応答の分子機構解明を軸として「量の差を質の違いへ」という細 胞内情報処理システムの作動機序を明らかにすること, (2) 炎症に伴う組織変性疾患 治療法ならびに予防法を開発するために細胞死のシグナル伝達に広く共通する分子 メカニズムを明らかにすることの 2 点を大きな目標として，多種多様ストレスなら びにアポトーシスのシグナル伝達機構として働くことが明らかになりつつある ASK1-MAP キナーゼ系(Ichijo, Science, 1997)の分子制御機構について研究を行 なっている.

これまでに，以下に挙げるような ASK1 活性制御分子機構がアポトーシスの刺激 特異的に機能していることを明らかにしてきた。

1 ）活性酸素に代表される酸化ストレスは, ASK1のN 末端領域に結合し ASK1 活 性を負に制御しているチオレドキシンを酸化し, 不活性化することによって ASK1MAP キナーゼ系を活性化する(Saitoh, EMBO J., 1998).

2) TNF からのシグナルでは, TNFレセプターのアダプター分子 TRAF2 がチオ 
レドキシンを酸化ストレス依存性に不活化するとともに，さらにASK1 のC 末端領 域ならびに N 末端領域に結合し，ASK1-MAP キナーゼ系を活性化する (Nishitoh, Mol. Cell, 1998 ; Liu, Mol. Cell Biol., 2000).

3 ) 構成的活性化型 ASK1 を用いた実験により, 細胞内での ASK1 の活性化はアポ トーシスのみならず，ASK1 の活性化の程度に応じて細胞の分化や生存を誘導する (Takeda, J. Biol. Chem., 2000).

4 ） ASK1 ノックアウトマウス由来の細胞は, 酸化ストレスによるJNK/p38 マッ プキナーゼの持続的活性化を特異的に欠失するとともにアポトーシス抵抗性となる (Tobiume, EMBO-R., 2001).

本講演では，酸化ストレスと ASK1 依存性アポトーシスの関係を中心に，ASK1MAP キナーゼ系の活性化程度 (量の差)が，酸化ストレスや小胞体ストレスによる 細胞の運命(質の違い)の決定に極めて重要な働きをすることを紹介したい. 